\title{
Long term changes in human corneal endothelium following toxic endothelial cell destruction: a specular microscopic and fluorophotometric study
}

Rudy M M A Nuyts, Nicolien Boot, Jaap A van Best, Henry F Edelhauser, Adrian C Breebaart

\begin{abstract}
Aims-To investigate the long term relation between corneal thickness, endothelial morphometric variables, and endothelial permeability in patients with endothelial cell counts under 900 cells $/ \mathrm{mm}^{2}$ as a result of endothelial cell destruction after cataract surgery. Methods-Eighteen patients developed the so called toxic endothelial cell destruction (TECD) syndrome following routine cataract surgery because of the intracameral injection of a toxic detergent residue. Ten patients with a mean (SEM) initial cell loss of $72 \%(2 \%)$ were followed for 4 years. Data were obtained at 6 months and 4 years postoperatively and compared between TECD eyes and contralateral control eyes.
\end{abstract}

Results-Mean (SEM) endothelial cell density of the TECD eyes increased from 642 (41) cells $/ \mathrm{mm}^{2}$ to $849(50)$ cells $/ \mathrm{mm}^{2}$ at 4 years postoperatively $(p=0 \cdot 005)$. There was no difference in coefficient of variation or percentage hexagonals between 6 months and 4 years postoperatively. Mean (SD) corneal thickness of the TECD eyes and control eyes was similar, $0.51(0.02) \mathrm{mm}$ and $0.49(0.01) \mathrm{mm}$, respectively $(p=0.65)$. Mean (SD) endothelial permeability was also similar for TECD eyes and control eyes $\left(4.3(0.9) \times 10^{-4} \mathrm{~cm} / \mathrm{min}\right.$ and 4.4 $(0.6) \times 10^{-4} \mathrm{~cm} / \mathrm{min}$, respectively $(p=0.57)$. There was no correlation between endothelial cell density, coefficient of variation, or percentage of hexagonal cells and endothelial permeability in the TECD eyes. In three patients a permanent corneal decompensation occurred.

Conclusions-Four years after TECD corneal endothelial wound healing is stable and the barrier function has been restored. (Br f Ophthalmol 1996; 80: 15-20)

In 1990 we described a series of patients who developed an acute corneal decompensation following routine cataract extraction in 1988 , characterised by star-shaped endothelial folds and a twofold increase in corneal thickness (Fig 1). ${ }^{1}$ This toxic endothelial cell destruction (TECD) syndrome was caused by the intracameral injection of a toxic detergent residue inside reusable irrigating cannulas. ${ }^{2}$ The cannula was previously used to inject a viscoelastic substance and the detergent was probably combined with the residual viscoelastic material. Endothelial morphometric analysis showed a mean (SEM) endothelial cell loss of $72 \%(2 \%), 3$ and 6 months postoperatively compared with the contralateral eyes. Endothelial wound healing, as determined by coefficient of variation and percentage hexagonals, was stable 6 months postoperatively.

There are numerous published studies on the morphometric follow up of the corneal endothelium after routine cataract surgery. ${ }^{3-13}$ Usually, a cell loss of 10 to $20 \%$ is reported, dependent on the duration of follow up. Few reports exist on the long term follow up of patients who developed severe endothelial cell loss at the time of surgery. ${ }^{14-16}$ It is thought that after severe cell loss, as is described in our series, there will be increased cell loss of the corneal endothelium, similar to that attributed to the aging effect. ${ }^{15-17}$ Consequently, permanent decompensation of these compromised corneas may occur. It is also possible that a low endothelial cell density and an unstable monolayer may decrease the barrier function of the corneal endothelium.

The purpose of this study was to investigate the long term relation between corneal thickness, endothelial morphometric variables, and endothelial permeability in a series of 10 patients with initial endothelial cell counts under 900 cells $/ \mathrm{mm}^{2}$.

\section{Materials and methods}

MORPHOMETRIC ANALYSIS

Non-contact specular microscopy of the central cornea (Nikon camera, Tokyo, Japan)

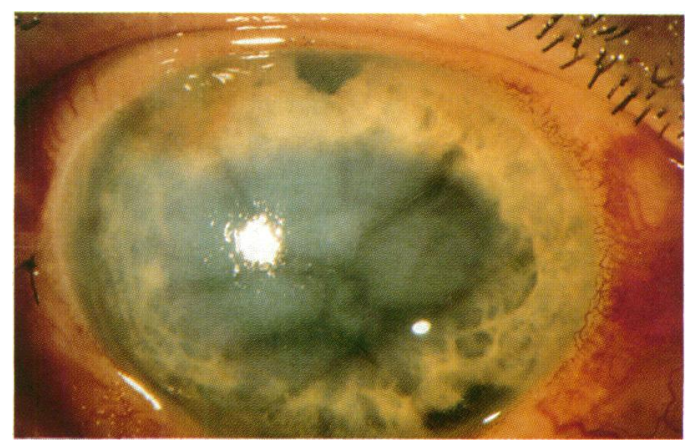

Figure 1 Case 9. Corneal decompensation 1 month after extracapsular cataract extraction. Note the extensive corneal clouding. 
of the initially decompensated and the unaffected contralateral eyes was performed at 6 months after intraocular surgery. Of the 18 patients with TECD three patients died, two underwent keratoplasty, one left the country, and two patients refused participation in the study. Specular photographs of the remaining 10 patients were used for morphometric analysis 4 years postoperatively. The age of these subjects ranged from 32 to 85 years (mean 66.8 years). The endothelial photographs were analysed using 100 cells per photograph as previously described for morphological analysis. ${ }^{18}$ Briefly, endothelial photographs of the central corneal endothelium were selected randomly and analysed in a masked fashion by the same technician using 100 neighbouring cells from one specular micrograph. Cell morphological variables studied included endothelial cell size $\left(\mu \mathrm{m}^{2}\right)$, endothelial cell density (ECD, number of cells $/ \mathrm{mm}^{2}$ ), coefficient of variation in cell size, and percentage of hexagonal cells (\%). We compared the values of the eyes with the TECD syndrome with the contralateral eyes using the Wilcoxon signed rank test. In addition, we performed a repeated measures analysis of variance to determine changes in mean cell area (SD) between 6 months and 4 years postoperatively.

ENDOTHELIAL PERMEABILITY MEASUREMENTS Patients 1 and 6 refused participation in the study because of general health problems precluding the intensive examination of the experiment itself. Three participating patients had systemic disease including one patient with coronary heart disease (patient no 5), one patient with hypertension and peripheral vascular disease (patient no 8 ), and one with diabetic mellitus (patient no 10). Systemic medication included insulin (patient no 10), anticoagulation drugs (patients 8 and 5), diuretics (patient no 8), anti-anxiety drugs (patient no 5), and $\mathrm{H}_{2}$ receptor blocking agents (patient no 7). Any local eye medication was interrupted 2 days before measurement of the endothelial permeability, except for patient no 10 , who continued timolol maleate $0.5 \%$ eyedrops once daily in both eyes. Previous ocular surgery and ocular abnormalities of the contralateral eye were registered. Informed consent was obtained from each patient after the nature of the procedure was fully explained. Slit-lamp biomicroscopy and ophthalmoscopy of the eyes were performed 2 weeks before measurement of the endothelial permeability. Both corneas were examined to assess signs of epithelial lesions, corneal oedema, or guttata. The thickness of the cornea was measured by optical pachymetry with the Haag-Streit slit-lamp. On the day of fluorophotometry, four drops of a $10 \%$ fluorescein solution were instilled in the conjunctival sac of both eyes with an interval of 2-4 minutes. Excess fluorescein was removed from the eyelids with moistened tissues. The fluorescein concentration in the cornea and anterior chamber was measured four times at 4, 5, 6 , and 7 hours after instillation of the drops using the Fluorotron Master (Coherent Radiation Inc, Palo Alto, CA, USA) equipped with an anterior segment adaptor. ${ }^{19}$ The patient was asked to blink just before the start of the fluorophotometry scan, and to suppress the blinking reflex during the experiment. At the end of the measurements slit-lamp examination of both eyes was performed to check the corneas for any irregularities.

\section{CALCULATIONS}

Quantitative measurements of endothelial permeability were performed according to the methods and calculations as described by Van Best $e t$ al in a large European multicentre study using a standardised protocol. ${ }^{19}$ For determination of endothelial permeability the following expression was used:

$$
\mathrm{P}=\mathrm{d}_{\mathrm{cm}} \cdot \alpha_{\mathrm{c}} \cdot \frac{\mathrm{C}_{\mathrm{c}}}{\mathrm{r}_{\mathrm{ac}} \cdot \mathrm{C}_{\mathrm{c}}-\mathrm{C}_{\mathrm{a}}} \quad(\mathrm{m} / \mathrm{s})
$$

with $P$ is endothelial permeability, $d_{c m}$ is the corneal thickness, $\alpha_{c}$ is a decay constant for the fluorescein concentration in the cornea approximated by a single exponential curve, $\mathrm{C}_{c}$ and $\mathrm{C}_{\mathrm{a}}$ are the fluorescein concentrations in the cornea and anterior chamber $\left(\mathrm{kg} / \mathrm{m}^{3}\right)$ and $r_{a c}$ is the unbound part of corneal fluorescein. Fluorophotometry measurements in the cornea and anterior chamber were corrected for autofluorescence and the fluorescein concentration in the cornea for limited spatial resolution with a factor 1.57 . The $r_{a c}$ value corresponds to the steady state ratio between anterior chamber and cornea and a value of 0.64 was used. The values for corneal and anterior chamber autofluorescence were 13.5 ng Eq/ml and $2.5 \mathrm{ng} \mathrm{Eq} / \mathrm{ml}$, respectively. The corneal and anterior chamber fluorescence values $C_{c}\left(t_{m}\right)$ and $C_{a}\left(t_{m}\right)$ are determined for $t_{m}=240,300,360$, and 420 minutes and corrected for autofluorescence.

Comparisons and correlations between measured values were performed and analysed using the Mann-Whitney $U$ test and the nonparametric Spearman correlation test.

\section{Results}

Table 1 summarises the morphometric analysis performed on the 10 patients. Six months postoperatively the mean (SEM) of the endothelial cell density was $642(43.4)$ cells $/ \mathrm{mm}^{2}$ and $2345(184.4)$ cells $/ \mathrm{mm}^{2}$ for the TECD eyes and contralateral eyes, respectively. The lowest cell count was $463 \mathrm{cells} / \mathrm{mm}^{2}$ (case no 10) and the highest cell count 898 cells $/ \mathrm{mm}^{2}$ (case no 5 ). The mean (SEM) percentage cell loss, compared with the contralateral eyes, at 6 months was $72 \%$ (2\%). At 4 years postoperatively, endothelial cell density was $849(52 \cdot 1)$ cells $/ \mathrm{mm}^{2}$ and $2128(165 \cdot 0)$ cells $/ \mathrm{mm}^{2}$ for the TECD eyes and contralateral eyes, respectively. The lowest cell count was 625 cells $/ \mathrm{mm}^{2}$ (case no 8) and the highest cell count 1103 cells $/ \mathrm{mm}^{2}$ (case no 9). The average percentage cell loss at 4 years was $60 \%(2 \%)$, compared with the contralateral eyes. There 
Table 1 Specular microscopy and permeability data after toxic endothelial cell destruction syndrome

\begin{tabular}{|c|c|c|c|c|c|c|c|c|c|c|c|}
\hline \multirow[b]{2}{*}{ No, age, sex } & \multicolumn{2}{|c|}{ Cell area $O E^{\star}\left(\mu m^{2}\right)$} & \multicolumn{2}{|c|}{ Cell area $C E^{\star}\left(\mu m^{2}\right)$} & \multicolumn{2}{|c|}{$\begin{array}{l}\text { Percentage } \\
E C D^{\star \star} \text { difference } \\
O E \text { vs } C E\end{array}$} & \multicolumn{2}{|c|}{$\begin{array}{l}\text { Endothelial } \\
\text { permeability } \\
\left(10^{-4} \mathrm{~cm} / \mathrm{min}\right)\end{array}$} & \multicolumn{2}{|c|}{$\begin{array}{l}\text { Corneal thickness } \\
\text { (mm) }\end{array}$} & \multirow[b]{2}{*}{ Ocular history (CE) } \\
\hline & 6 Months & 4 Years & 6 Months & 4 Years & 6 Months & 4 Years & $O E$ & $C E$ & $O E$ & $C E$ & \\
\hline $\begin{array}{l}1,70, \mathrm{~F} \\
2,60, \mathrm{~F} \\
3,59, \mathrm{~F} \\
4,85, \mathrm{M} \\
5,75, \mathrm{~F} \\
6,80, \mathrm{~F} \\
7,80, \mathrm{M} \\
8,76, \mathrm{~F} \\
9,32, \mathrm{~F} \\
10,51, \mathrm{M}\end{array}$ & $\begin{array}{l}2059(519) \\
1836(523) \\
1442(469) \\
1759(573) \\
1116(373) \\
1457(335) \\
1557(793) \\
1225(260) \\
2036(677) \\
2158(1159)\end{array}$ & $\begin{array}{r}1313(346) \\
1088(260) \\
1160(343) \\
1460(416) \\
916(234) \\
1118(405) \\
1157(271) \\
1600(611) \\
907(415) \\
1468(391)\end{array}$ & $\begin{array}{l}347(113) \\
676(175) \\
339(114) \\
527(186) \\
386(118) \\
595(168) \\
467(126) \\
430(121) \\
386(96) \\
532(385)\end{array}$ & $\begin{array}{l}762(203) \\
644(182) \\
371(121) \\
488(190) \\
385(105) \\
581(181) \\
346(92) \\
542(140) \\
418(97) \\
450(337)\end{array}$ & $\begin{array}{l}83 \\
63 \\
77 \\
70 \\
65 \\
59 \\
80 \\
65 \\
77 \\
75\end{array}$ & $\begin{array}{l}42 \\
41 \\
68 \\
67 \\
58 \\
48 \\
70 \\
66 \\
54 \\
69\end{array}$ & $\begin{array}{l}- \\
6 \cdot 70 \\
3 \cdot 00 \\
1 \cdot 20 \\
3.90 \\
- \\
3.90 \\
9 \cdot 50 \\
2 \cdot 30 \\
3.90\end{array}$ & $\begin{array}{l}- \\
4 \cdot 10 \\
3 \cdot 60 \\
2 \cdot 80 \\
4 \cdot 40 \\
- \\
4 \cdot 20 \\
6 \cdot 40 \\
7 \cdot 50 \\
2 \cdot 50\end{array}$ & $\begin{array}{l}- \\
0 \cdot 58 \\
0 \cdot 54 \\
0 \cdot 48 \\
0 \cdot 47 \\
\overline{0} \\
0 \cdot 60 \\
0.50 \\
0 \cdot 50 \\
0.44\end{array}$ & $\begin{array}{l}\overline{0} \\
0.52 \\
0.54 \\
0.48 \\
0.49 \\
\overline{0} \\
0.54 \\
0.47 \\
0.50 \\
0.44\end{array}$ & $\begin{array}{l}\text { ECCE+PCL†, POAG } \\
\text { ECCE+PCL } \\
\text { PACGS } \\
\text { POAG } \\
\text { ECCE+PCL } \\
\text { None } \\
\text { ECCE+PCL } \\
\text { ECCE+PCL } \\
\text { Panuveitis } \\
\text { ECCE + ACL }\end{array}$ \\
\hline
\end{tabular}

${ }^{\star}$ Mean (SD) cell area in operated eye (OE) and control eye (CE); ${ }^{\star \star}$ percentage of endothelial cell density (ECD) difference between the operated eye and contralateral eye; fextracapsular cataract extraction with posterior chamber lens implant; łprimary open angle glaucoma; Sprimary angle closure glaucoma; Iextracapsular cataract extraction with anterior chamber lens implant.

was an increase in the mean endothelial cell density of the TECD eyes between 6 months and 4 years postoperatively $(p=0.005$, Wilcoxon signed rank test). There was a significant decrease in cell area of TECD eyes between 6 months and 4 years postoperatively $(\mathrm{p}<0.001$, Bonferroni repeated measures analysis of variance). There was no difference in cell area for the contralateral eyes or for the standard deviations of the individual cell areas of both TECD eyes and contralateral eyes between 6 months and 4 years postoperatively ( $p>0.05$, Bonferroni repeated measures analysis of variance). One eye of the TECD eyes had epithelial and stromal oedema (patient no 2) and the TECD eye of patient no 7 had corneal guttata without oedema. Patient no 8 had severe corneal guttata and endothelial oedema in both eyes. Patient no 4 had mild corneal guttata in the control eye. Figure 2 shows the endothelial photographs of case no 3 during the 4 year follow up period. The endothelial micrograph 4 years after endothelial cell destruction shows a restored monolayer.

There was no significant difference in endothelial coefficient of variation between TECD eyes and contralateral eyes at any time (Table 2). At 6 months postoperatively but not at 4 years postoperatively, there was a significant difference in the percentages of hexagonal cells between TECD eyes and the contralateral eyes (Table 2, $p=0.01$ and $p=0.19$, respectively). There was no significant change in percentages of hexagonal cells for TECD eyes or contralateral eyes from 6 months to 4 years postoperatively $(p=0.85$ and $p=0.08$, respectively). The mean endothelial permeability values of the TECD eyes and of the control eyes were similar, $4.3(0.9) \times 10^{-4} \mathrm{~cm} / \mathrm{min}$ and $4 \cdot 4(0 \cdot 6) \times 10^{-4} \mathrm{~cm} / \mathrm{min}$, respectively (Table 2 , $\mathrm{p}=0.57)$. There was no significant difference in endothelial permeability between TECD eyes and the control eyes of five patients who had undergone an extracapsular cataract extraction in the control eye, $5.6(1 \cdot 1) \times 10^{-4} \mathrm{~cm} / \mathrm{min}$ versus $4.3(0.6) \times 10^{-4} \mathrm{~cm} / \mathrm{min}$, respectively $(p=1 \cdot 0)$. No correlation was found between endothelial cell density, coefficient of variation, or percentage of hexagonal cells and endothelial permeability in the TECD eyes $(p=0.50, p=0.43$, and $p=0.88$, respectively; non-parametric Spearman correlation test).

Mean corneal thickness of the eyes with TECD and those of the control eyes was similar, $0.51(0.02) \mathrm{mm}$ and $0.49(0.01) \mathrm{mm}$, respectively $(p=0 \cdot 65)$. There was no correlation between the corneal thickness and the endothelial permeability in the TECD eyes or the control eyes $(p=0.65$ and $p=0.50$, nonparametric Spearman correlation test).

\section{Discussion}

This study represents the first series of patients with long term follow up of endothelial morphometry and fluorophotometry after severe endothelial cell loss due to toxic endothelial cell destruction. We believe that the clinical picture of this particular group of patients differs from the usual postcataract patient group with respect to endothelial wound healing characteristics. After routine cataract surgery the greatest cell loss is usually in the superior cornea, since the incision is made superiorly and the lens extraction is most traumatic to the superior cornea. ${ }^{4}$ However, in the TECD group extensive cell loss occurred in the central cornea, as a result of the circulation of the toxic substance in the anterior eye chamber. Therefore the great cell loss centrally may lead to a spreading and migration response of the peripheral corneal endothelium towards the central cornea. Another explanation for the increase in central endothelial cell density from 649 to 839 cells $/ \mathrm{mm}^{2}$ after 4 years could be that the cell density increased through cell division. Although the mitotic activity of the human

Table 2 Summary of specular microscopy and endothelial permeability data (mean (SEM))

\begin{tabular}{|c|c|c|c|c|c|c|c|c|}
\hline \multirow[b]{2}{*}{ Follow up } & \multicolumn{2}{|c|}{$\begin{array}{l}\text { Endothelial cell density } \\
\left(\text { cells } / \mathrm{mm}^{2}\right)\end{array}$} & \multicolumn{2}{|c|}{ Coefficient of variation } & \multicolumn{2}{|c|}{$\begin{array}{l}\text { Percentage hexagonals } \\
(\%)\end{array}$} & \multicolumn{2}{|c|}{$\begin{array}{l}\text { Endothelial permeability } \\
\left(10^{-4} \mathrm{~cm} / \mathrm{min}\right)\end{array}$} \\
\hline & $T E C D$ & Control & $T E C D$ & Control & $T E C D$ & Control & $T E C D$ & Control \\
\hline $\begin{array}{l}6 \text { Months } \\
4 \text { Years }\end{array}$ & $\begin{array}{l}642(43 \cdot 6) \\
849(52 \cdot 1)^{\star}\end{array}$ & $\begin{array}{l}2345(184 \cdot 4) \\
2128(165 \cdot 0)\end{array}$ & $\begin{array}{l}0.33(0.03) \\
0.30(0.02)\end{array}$ & $\begin{array}{l}0.34(0.04) \\
0.34(0.05)\end{array}$ & $\begin{array}{l}53(4 \cdot 0) \\
55(2 \cdot 0)\end{array}$ & $\begin{array}{l}64(2 \cdot 7)^{\star} \\
60(2 \cdot 7)\end{array}$ & $\overline{4} \cdot 3(0.9)$ & $\overline{4} \cdot 4(0 \cdot 6)$ \\
\hline
\end{tabular}

${ }^{\star} \mathrm{p}=0.005$ compared with TECD eye at 6 months. 
Figure 2 Case 3. (A) Endothelial micrograph of the eye with toxic

endothelial cell destruction (TECD) 6 months after cataract surgery. Note the endothelial oedema and large cells. The endothelial cell density is 694 cells $/ \mathrm{mm}^{2}$. (B) Endothelial cell layer of the TECD eye 2 years after cataract surgery shows a regular endothelial cell layer with an endothelial cell density of 919 cells $/ \mathrm{mm}^{2}$. (C)

Four years after surgery the endothelial monolayer is still intact. No endothelial oedema is seen and the endothelial cell density is $861 \mathrm{cells} / \mathrm{mm}^{2}$. (D) The unoperated contralateral eye shows a regular endothelial monolayer with an endothelial cell density of $2699 \mathrm{cells} / \mathrm{mm}^{2}$.
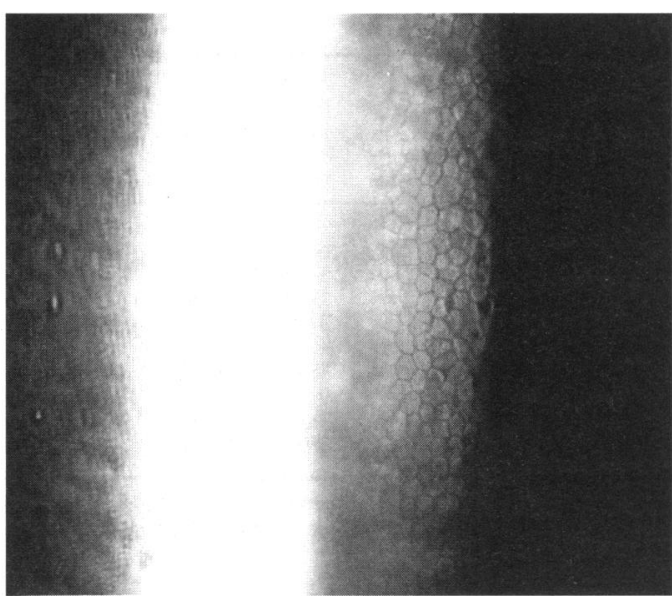

Fig $2 A$

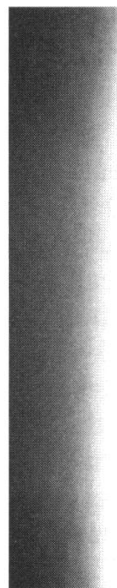

Fig 2C

corneal endothelium is very limited, some mitosis of the endothelium has been described in vitro and in vivo. ${ }^{20-22}$ In cats, also a species with very limited replication of corneal endothelial cells, centrally induced mechanical trauma also led to a slight increase in endothelial cell density after 18 months. ${ }^{23}$ In addition to the aforementioned hypotheses for the increase in endothelial cell density, it is known that the accuracy of endothelial cell density measurements sometimes can be questioned and considerable sample errors may occur. ${ }^{24}$ However, the stability of the mean endothelial cell area in the control eyes and the lack of a significant difference between standard deviations of cell area for both TECD eyes and control eyes suggest an accurate method of specular microscopy and endothelial morphometry.

There are studies that have established the factors of endothelial function after cataract surgery used to predict future endothelial decompensation. ${ }^{14-16}$ It is believed that large endothelial cell loss in the early postoperative phase is a risk factor for future endothelial decompensation. ${ }^{1516}$ Hoffer described a case report of a patient with a cell count of 370 cells $/ \mathrm{mm}^{2}$, who developed a bullous keratopathy 1 year after this measurement. ${ }^{14}$ In our series with morphometry data only one patient, patient no 2, developed a corneal decompensation 9 months after the 4 year follow up specular photography and fluorophotometry
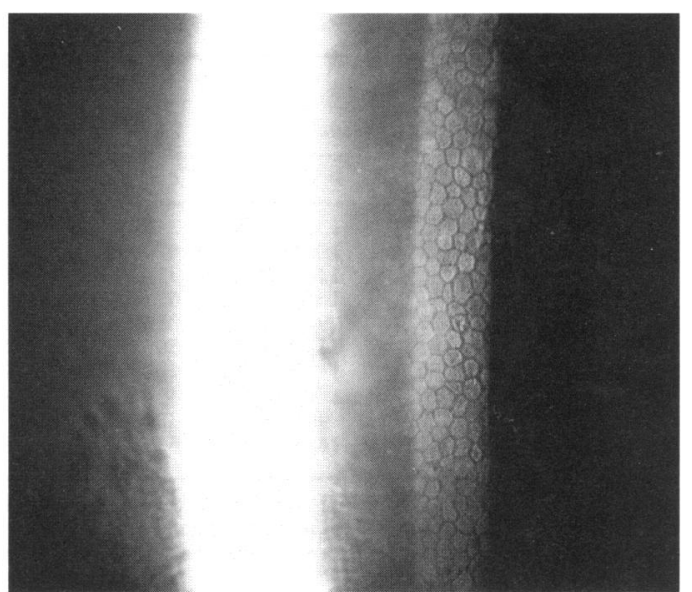

Fig $2 B$
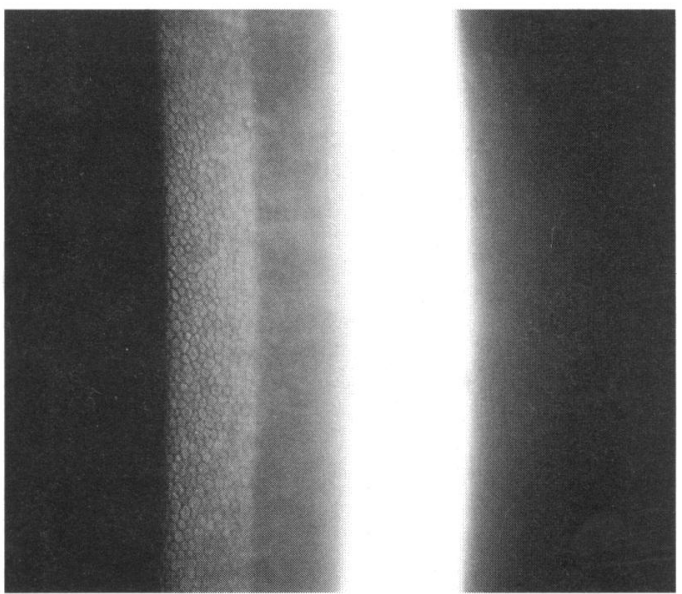

Fig 2D

measurements. At that time, the endothelial cell density was 919 cells $/ \mathrm{mm}^{2}$, much higher than the patient reported by Hoffer. Unfortunately, the two other patients in this group who needed a corneal transplantation never recovered clear corneas after the initial decompensation that permitted specular microscopy.

Bates emphasised the importance of the first postoperative month cell loss as a predictor for bullous keratopathy with long term follow up. ${ }^{1516}$ In a longitudinal study on endothelial morphometry after cataract surgery he found a mean endothelial cell density of 1726 (647) cells $/ \mathrm{mm}^{2} 6$ months after surgery, in a group of patients who ultimately would develop a bullous keratopathy. The mean time period for corneal decompensation after cataract surgery was 3.5 years postoperatively and the mean endothelial cell density at this point was 515 (97) cells $/ \mathrm{mm}^{2}$. Obviously, despite even a lower mean cell density 6 months postoperatively, cell loss in the TECD group does not progress in the same rate as reported by Bates. In Bates's series factors like low grade uveitis, vitreous loss during cataract surgery, or intraocular lens malposition may have contributed to a continuous, possibly immune mediated, damaging effect on the endothelial monolayer.

Other authors suggest that the preoperative coefficient of variation and percentage of 
hexagonal cells are related to the risk for the development of postoperative corneal oedema and susceptibility to surgical trauma. ${ }^{25}$ This point has been confirmed in corneal endothelial wound healing studies of cats, where a correlation was found between permanent endothelial decompensation and a decrease of endothelial cell density to $40 \%$ of baseline values, a decrease in hexagonals to $33 \%$, and a three to fourfold increase in coefficient of variation, respectively. ${ }^{26}$ In addition, a correlation also was shown between endothelial dysfunction and the occurrence of giant endothelial cells with a surface area $7 \cdot 5-13.5$ times of normal endothelial cells. ${ }^{26}$ Despite our high initial cell loss of $72 \%$ we were unable to demonstrate a similar relation. Furthermore, no statistical difference was found for either the coefficient of variation or the percentage of hexagonal cells between 6 months and 4 years postoperatively suggesting that a stable endothelial layer can be maintained for more than 4 years, even after severe cytotoxicity trauma to the corneal endothelium.

Our study showed no correlation between endothelial permeability and the endothelial variables of wound healing 4 years after severe endothelial trauma. The corneal endothelial permeability of the TECD eyes was within the range of normal values as reported by various investigators. ${ }^{19} 27-29$ These results are in accordance with earlier reports that showed a return of endothelial permeability to normal values 3 months after routine cataract surgery. ${ }^{30}$ Similarly, endothelial permeability returned to normal values 3 months after traumatic wounding of cat endothelium. ${ }^{31}$ However, other studies have shown increased endothelial permeability values within 3 months after intraocular surgery. ${ }^{32}$ One study in patients after keratoplasty showed a decreased endothelial permeability, possibly owing to the decrease in intercellular space which could be the result of the increased incidence of giant endothelial cells. ${ }^{33}$ Despite the prevalence of many large endothelial cells in our series we were unable to confirm these findings. Based on our results it appears that the endothelial permeability, even after extensive endothelial cell destruction, does not increase as long as a restored monolayer is present. However, in cases with a disruption or a stressed state of the monolayer, as was seen in the patients with corneal oedema or guttata, increased permeability values were determined.

After severe endothelial cell loss a delicate balance between corneal oedema and clarity exists. At present, we do not know to what extent the endothelial pump should increase its activity in corneas with low cell counts to maintain corneal clarity. Probably, different stress factors to the corneal endothelium should be discerned: an acute toxicity mechanism with extensive endothelial cell loss, followed by a quick response in recovery of corneal clarity and stabilisation of the monolayer versus a gradual cell loss associated with the presence of a continuous inflammatory stimulus. These additional stimuli may exceed the capacity of the endothelial pump and/or the endothelial barrier in a compromised endothelium to maintain corneal clarity. Previous studies support this hypothesis since intraocular inflammation has been shown to affect corneal oedema by both an increase in endothelial permeability and a decrease in $\mathrm{Na} / \mathrm{K}$ ATPase pump site density. ${ }^{34}$

In summary, the results of this study suggest that the human corneal endothelium can recover from toxic endothelial cell destruction provided there are enough endothelial cells to migrate over Descemet's membrane and reestablish the barrier. In this series of patients, the majority recovered; however there were three patients where the endothelial cell destruction exceeded the ability of the endothelial cells to recover, and the cornea decompensated.

Supported by the Dutch Corneal Society, the Rotterdam Foundation to prevent Blindness, and NEI grant EY00933.

1 Breebaart AC, Nuyts RMMA, Pels E, Verbraak FD. Toxic endothelial cell destruction of the cornea after routine exdothelial cell destruction of the cornea after routine 108: 1121-5.

2 Nuyts RMMA, Edelhauser HF, Pels E, Breebaart AC. Toxic effects of detergents on the corneal endothelium. Arch Ophthalmol 1990; 108: 1158-62.

3 Liesegang TJ, Bourne WM, Ilstrup DM. Short- and longterm endothelial cell loss associated with cataract extraction and intraocular lens implantation. Am f Ophthalmol 1984; 97: 32-9.

4 Schultz RO, Glasser DB, Matsuda M, Yee RW, Edelhauser HF. Response of the endothelium to cataract surgery. Arch Ophthalmol 1986; 104: 1164-9.

5 Matsuda $M$, Miyake $K$, Inaba $M$. Long-term corneal endothelial changes after intraocular lens implantation. Am $f$ Ophthalmol 1988; 105: 248-52.

6 Yee RW, Matsuda M, Schultz RO, Edelhauser HF. Changes in the normal corneal endothelial cellular pattern as a function of age. Curr Eye Res 1985; 4: 671-8.

7 Kraff MC, Sanders DR, Liebermann HL. Specular microscopy in cataract and intraocular lens patients. Arch Ophthalmol 1980; 98: 1782-4.

8 Rao GN, Stevens RE, Harris JK, Aquavella JV. Long-term changes in corneal endothelium following intraocular lens implantation. Ophthalmology 1981; 88: 386-97.

9 Kraff MC, Sanders DR, Liebermann HL. Monitoring for continuous cell loss with cataract extraction and intraocular lens implantation. Ophthalmology 1982; 89: 30-4.

10 Azen SP, Hurt A, Steel D. Effects of the Shearing posterior chamber intraocular lens on the corneal endothelium. Am f Ophthalmol 1983; 95: 798-802.

11 Matsuda $M$, Suda $T$, Manaba $R$. Serial alterations in endothelial cell shape and pattern after intraocular surgery. Am f Ophthalmol 1984; 98: 313-9.

12 Oxford cataract treatment and evaluation team (OCTET). Long-term corneal endothelial cell loss after cataract surgery. Arch Ophthalmol 1986; 104: 1170-5.

13 Liesegang TJ. The response of the corneal endothelium to intraocular surgery. Refract Corneal Surg 1991; 7: 81-6. 14 Hoffer KJ. Corneal decomposition after corneal endothelium cell count. Am $\mathcal{f}$ Ophthalmol 1979; 87: 252-3

15 Bates AK, Cheng H, Hiorns RW. Pseudophakic bullous keratopathy: relationship with endothelial cell density and use of a predictive cell loss model. Curr Eye Res 1986; 5: 363-6.

16 Bates AK, Cheng $\mathrm{H}$. Bullous keratopathy: a study of endothelial cell morphology in patients undergoing cataract surgery. Br f Ophthalmol 1988; 72: 409-12.

17 Mishima S. Clinical investigations on the corneal endothelium. Am f Ophthalmol 1982; 93: 1-29.

18 Schultz RO, Matsuda M, Yee RW, Edelhauser HF, Schultz KJ. Corneal endothelial changes in type 1 and type 2 KJ. Corneal endothelial changes in type 1 and type

19 Best JA van, Diestelhorst M, Leite E, Fantaguzzi S, Schalnus R. Corneal endothelial permeability and aqueous humor flow using a standard protocol.Graefes Arch Clin Exp Ophthalmol (in press).

20 Treffers WF. Human corneal endothelial wound repair. In vitro and in vivo. Ophthalmology 1982; 89: 605-13.

21 Singh G. Mitosis and cell division in human corneal endothelium. Ann Ophthalmol 1986; 18: 88-94.

22 Laing RA, Neubauer L, Oak SS, Kayne HL, Leibowitz HM. Evidence for mitosis in the adult corneal endothelium. Ophthalmology 1984; 91: 1129-34.

23 Ling TL, Vannas A, Holden BA. Long-term changes in endothelial morphology following wounding in the cat. Invest Ophthalmol Vis Sci 1988; 29: 1407-12. 
24 Hirst LW, Yamauyoshi K, Enger C, Vogelpohl W, Whittington V. Quantitative analysis of wide-field specular microscopy. II. Precision of sampling from the central corneal endothelium. Invest Ophthalmol Vis Sci 1989; 9: 1972-9.

25 Rao GN, Aquavella JV, Goldberg SH, Berk SL. Pseudophakic bullous keratopathy. Ophthalmology 1984; 91: $1135-40$.

26 Landshman N, Ben-Hanaan I, Assia E, Ben-Chaim O, Belkin M. Relationship between morphology and functional ability of regenerated corneal endothelium. Invest tional ability of regenerated corneal
Ophthalmol Vis Sci 1988; 29: 1100-9.

27 Carlson KH, Bourne WM. The clinical measurement of endothelial permeability. Cornea 1988; 7: 183-9.

28 Carlson KH, Bourne WM, Brubaker RF. Effect of long term contact lens wear on corneal endothelial cell morphology and function. Invest Ophthalmol Vis Sci 198; 29: 185-93.

29 Kuppens EVMJ, Stolwijk TR, Genderen MM van, Keizer RWJ de, Best JA van. Corneal endothelial permeability and aqueous humor dynamics in normal pressure glaucoma. Int Ophthalmol (in press).

30 Sawa M, Sakanishi Y, Shimizu H. Fluorophotometric study of anterior segment barrier functions after extracapsular cataract extraction and posterior chamber intraocular lens implantation. Am $\mathcal{f}$ Ophthalmol 1984; 97: 197-204.

31 Huang PT, Nelson LR, Bourne WM. The morphology and function of healing cat corneal endothelium. Invest function of healing cat corneal end

32 Sawa M, Araie M, Tanishima TA. Fluorophotometric study of the barrier functions in the anterior segment of the eye of the barrier functions in the anterior segment of the eye
after intracapsular cataract extraction. $\mathscr{f} p$ $\mathcal{F}$ Ophthalmol 1983; 27: 404-15.

33 Bourne WM, Brubaker RF. Decreased endothelial permeability in transplanted corneas. Am F Ophthalmol 1983; 96: 362-7.

34 MacDonald JM, Geroski DH, Edelhauser HF. Effect of inflammation on the corneal endothelial pump and barrier. Curr Eye Res 1987; 6: 1125-32. 